Pehkonen, Samu (2018). Impromptu facts and moral panic: the Roma people and local communities. In Ojala-Fulwood, Maija (ed.). Migration and Multi-ethnic Communities. Mobile People from the Late Middle-Ages to the Present. DeGruyter Oldenbourg, 217-238.

\title{
Impromptu facts and moral panic: the Roma people and local communities
}

Samu Pehkonen

\section{Positioning the Roma}

"[T]here is a lot of talk in the media about FEUDING NEIGHBORS or CONFLICTS in the village. That's bullshit! This is a Gypsy problem, nothing else. No Gypsies, no feuding neighbors. The Swedish media doesn't like this so they resort to using euphemisms to discuss the problem."1

"If someone gets pissed off because of me filming [the Gypsy beggars], I don't really care. I'm more pissed off by the fact that these parasites come to Finland and misuse our welfare system."2

These two quotations show some of the present-day reactions to the problematic position of the Roma (or Gypsy) people, a traditionally nomadic ethnic group. While attitudes toward immigrants of different ethnic backgrounds have generally become more polarized in Europe in the wake of the "refugee influx," the Roma hold an unfortunate record of perpetually being unwelcome everywhere. Also, in the Nordic countries, their mobile and culturally conservative way of life has made them a group with "traces of dubious origins,"3 who are not fully in synch with the prevailing Nordic public space and social order but tend to "stand out" as morally suspicious. ${ }^{4}$ The individual reactions quoted above are based on and reflect a growing collective moral panic, an emotional reaction to an issue deemed to be a threat to the sensibilities of "proper" society. The quotes also suggest that the Roma pose a challenge to society; "ordinary citizens" are losing their trust in authorities who are incapable of handling the Roma problem.

The fact that both these events are accessible to the public through various audio-visual and written records makes them an interesting starting point for this chapter. The first quotation from a Swedish internet forum relates to a neighborhood conflict that took place in Vojakkala village in Haparanda, Northern Sweden for more than two decades. It attracted nationwide media attention and culminated in attempted murder in 2008. The District Court sentenced six members of a Finnish Roma family to a total of 22 years' imprisonment. For some, the court decision provided evidence of the Swedish authorities finally putting an end to a Gypsy threat, while for others, it was just another example of injustice and anti-Roma sentiment.

The second quotation provides an argumentative basis for a self-proclaimed Finnish immigration critic who has been filming various encounters with Eastern European Roma beggars in Finland. These recordings are then posted on the internet and narratively reframed as witness to the failings of both national and European immigration policies, to show distrust toward authorities, and to flirt with vigilantism. Extending or criticizing the news coverage on the Roma beggars in the established media, this type of citizen journalism with biased emphasis aims to reframe public perceptions of and responsibilities toward the Roma. Just like "compassion depends on visuals," 5 so does suspicion and hate.

\footnotetext{
1 UT64 pseud., May 25, 2012, post to the thread "Grannfejden i Vojakkala [Feuding Neighbors in Vojakkala]," Flashback.org, accessed February 28, 2017, https://www.flashback.org/p37526982. Emphases in the original, all translations by SP.

2 Jon Rander pseud., March 24, 2013, "Tikkurilan asema 24.4. [Tikkurila station 24.4.]," Tikkurilan turistikeriäläiset Blog, accessed July 20, 2015, http://kerjalaiset.blogspot.fi/2013/03/assa-244.html.

3 Sara Ahmed, "A phenomenology of whiteness," Feminist Theory 8 (2007), 162.

4 Michele Lobo, "Everyday multiculturalism: catching the bus in Darwin, Australia," Social \& Cultural Geography 15 (2014), 719.

5 Birgitta Höijer, "The Discourse of Global Compassion: The Audience and Media Reporting of Human Suffering," Media, Culture \& Society 26 (2004), 520.
} 
Although the Roma in these two cases are ethnically different (i.e., in the neighbor conflict, the family belongs to a group of Finnish Kale Gypsies with a 500-year history of gradual integration into Finnish and Swedish societies, while the Roma beggars present a group of poverty-driven Roma whose recent mobility to Finland resulted from the Eastern enlargement of the European Union [EU] in 2007), the framing of the Roma problem is nevertheless very similar. A strong moral element persists in categorizing the Roma as parasites and troublemakers. This historically layered arguments made on the Roma people across Europe, linking them to "animal-like behavior, violence, immorality, deception and parasitism,"6 fuel hate speech and even physical harassment against the Roma. Also shared is a pessimistic view of the state authorities; the majority of the population questions the authorities' abilities and willingness to act under fear of being labelled "racist." Furthermore, in both cases, beneath the actual interactions swarm the circulation and production of truths and lies, a discussion where the other party - the Roma - is relegated to the position of muted objects. From the mainstream point of view, the Roma's agency is not considered, but rather, the morally suspicious outcomes of their actions are all that is counted.

My aim in this chapter is to walk through these documented encounters and to analyze morality as a practical accomplishment in a fashion inspired by the tradition of ethnomethodological research. 7 This perspective does not provide an answer to the question of why certain values are deemed moral/immoral at a particular moment in history. Neither is it an effort to moralize the dubious acts of those involved in the actions described. Rather, the ethnomethodological approach allows for an investigation of the mundane, of members' sense-making practices, and of how social and moral orders are interactionally negotiated and implemented. ${ }^{8}$ The documents used do not necessarily bring up historical facts, but rather, they reveal how turns in conversation are portrayed as "impromptu facts," information that is easy to find and that by intuition fits the situation. I argue that these impromptu facts are seemingly easy to "reuse" in other contexts where similar racist accusations are played out.

This chapter sheds light on the ways in which mundane racialist choreographies ${ }^{9}$ are enacted in the public space and for the public. I look at two layers of choreographed encounters between the Roma people and the majority of the population. The feuding neighbors builds on mediated reports of the attempted murder mainly news articles, court decisions, and internet discussion forums. The case of the street beggars builds on multimodal interaction analysis of the videos as records of street encounters. The chapter illustrates the methods participants use to manage and maintain their prospective projects in the heat of the interaction, and how the singular events are connected to broader historical cause-and-effect relationships. Finally, the chapter argues that by studying present-day racist encounters, we can detect how derogatory attitudes are legitimized by virtue of their historical factuality and supposed relationships. As historians and social scientists, we possess an obligation to guide the discussion toward including minorities' points of view. ${ }^{10}$

\section{From solitary events to impromptu facts and moral panic}

The two central concepts deployed here - moral panic and impromptu facts - need some further clarification. The concept of moral panic indicates that something is utterly threatening the well-being of society and its norms. The literature on moral panic highlights the role of mass media in defining what is morally beyond acceptable and in establishing an understanding that the deviant conduct in question is somehow symptomatic

\footnotetext{
6 David Mayall, "Egyptians and Vagabonds. Representations of the Gypsy in Early Modern Official and Rogue Literature," Immigrants \& Minorities 4 (1997), 71. See also, Nando Sigona, "Locating 'The Gypsy Problem'. The Roma in Italy: Stereotyping, Labelling and 'Nomad Camps'." Journal of Ethnic and Migration Studies 31 (2005), 746-47. Anne Hege Simonsen, "'Just like vacuum cleaning...': Reporting the Roma Beggar Tourists in Norway," in Media in motion: cultural complexity and migration in the Nordic region, edited by Elisabeth Eide and Kaarina Nikunen (Farnham: Ashgate, $2011)$, 93-94.

7 See, Dalvir Samra-Fredericks, "Ethnomethodology and the moral accountability of interaction: Navigating the conceptual terrain of 'face' and face-work," Journal of Pragmatics 42 (2010), 2147-49; Lena Jayyusi, "Values and Moral Judgment: Communicative Praxis as a Moral Order," in Ethnomethodology and the Human Sciences, edited by Graham Button (Cambridge: Cambridge University Press, 1991), 235 and passim.

8 Harold Garfinkel, Studies in Ethnomethodology (Englewood Cliffs: Prentice-Hall, 1967), 9-10.

9 For the development of this choreographic approach, see Tarja Väyrynen et al., Choreographies of Resistance. Mobile Bodies and Relational Politics (London \& New York: Rowman \& Littlefield, 2017), 10-19.

10 See Malte Gasche, "State regulation of the Roma in Finland. The international dimension and the minority perspective," Siirtolaisuus/Migration 43 (2016): 17.
} 
of wider moral, social, or cultural breakdowns in society. ${ }^{11}$ Equally important is the role that state authorities play in the production of panicking language. As Karina Horsti points out, the media often collaborate with state authorities in their mutual construction of frameworks of control to the degree that the origins of panic become blurred. ${ }^{12}$ For example, Anne Hege Simonsen has analyzed representations of Eastern European Roma beggars in Norway. Her analysis shows that the frames of the Roma as criminals, objects of control, and victims were circulated in both the language of state officials and news reporters, while the category of workers, the one that the Roma themselves made use of when giving accounts of their existence in Norway, was non-existent in the public debate. ${ }^{13}$

A further layer in the production of moral panic, one that connects it with impromptu facts, is formed by the moral entrepreneurs, such as active online commentators, "concerned members of the public," and selfproclaimed social critics, who often act on the front lines when something happens. Moral entrepreneurs are the ones who often make the first interpretations of solitary events and link them to existing categories and stereotypes, even in the absence of evidence of such connections. ${ }^{14}$ Psychologically, spreading misinformation is particularly effective when it appears early in the interpretation process. It can lead to what is called confirmation bias, a tendency to interpret information in a way that confirms one's pre-existing beliefs. ${ }^{15}$ In both cases analyzed here, the information available is used in a way that connects individuals' unacceptable conduct to a larger group of people; thus, individual members are portrayed as criminals, unintegrated, and parasites. As the two cases will show, face-to-face encounters on the street and the narrative structure of crime reporting are used to manipulate historical facts; or, if not the facts, at least their temporal and contextual order is distorted for the purpose of certain political agendas, in this case anti-Gypsyism. As the approach of this book is historical, my analytical workings on these cases emphasize the use of historical knowledge as well as the small details through which history is used as a resource in reframing single, often unrelated events into collective moral panic.

Before moving on, a few words about the research data are needed. Written and audio-visual documents from the not-so-distant past are used as semiotic sources handed down to the researcher who nevertheless needs to critically reflect on their value for the research question, as well as mirror the data against established historical research. This can be an arduous task as the chronology is not always clear since the same documents circulate in different discussion forums and threads, and documentary programs use the same audio-visual material in different contexts and for various purposes. In the case of the feuding neighbors, an alternative view of the conflict is not easily found due to the greater amount of outrageous material prevailing on social media. On the other hand, if one looks at the Wikipedia revision history of the Grönfors case, for example, it is obvious that the family's Roma background is a contested tool, and the authors purposefully use it in their efforts to challenge the event's image. Although the case is delicate in terms of the personal information available and the participants' backgrounds, it would have been impossible to anonymize the case. From an ethical point of view, I have taken into consideration that in academic research, the family deserves to be treated by name as a way to challenge the predominantly racist ways in which the case is continuously discussed anonymously online.

\section{A short (b)ordered history of the Finnish Roma}

The history of the Roma in Sweden began in 1512 when the first Gypsy families were reported to have arrived in Stockholm. ${ }^{16}$ The Stockholm Records book tells about this first encounter in a rather neutral tone:

\footnotetext{
11 David Garland, "On the Concept of Moral Panic," Crime, Media, Culture 4 (2008): 11. The concept of moral panic was introduced in Stanley Cohen, Folk Devils and Moral Panics: The Creation of the Mods and Rockers (London: MacGibbon and Kee Ltd, 1973), chapter 1.

12 Karina Horsti, "Hope and Despair: Representations of Europe and Africa in Finnish news coverage of 'migration crisis'," Estudos em Comunicacao / Communication Studies 3 (2008), 131.

13 Simonsen, "'Just like vacuum cleaning...', 90.

14 This is why I prefer the phrase "impromptu facts," instead of "alternative facts," which presupposes that they are alternative to something (truth).

15 Raymond S. Nickerson, "Confirmation Bias: A Ubiquitous Phenomenon in Many Guises", Review of General Psychology 2 (1998), 187.

16 Panu Pulma, Suljetut ovet. Pohjoismaiden romanipolitiikka 1500-luvulta EU-aikaan [Closed doors: Nordic Romani policy from the 16th century to the EU era] (Helsinki: Suomalaisen Kirjallisuuden Seura, 2006), 20.
} 
"29 September 1512, On Archangel Saint Michael's Day Gypsies arrived in the city, coming - it was said - from the land of Little Egypt. They brought their wives and children with them, some only babies. They were accommodated in Saint Lars's shelter and numbered 30 couples. Their leader is named Count Anthonius. The city granted them 20 marks." 17

This entourage was part of the 16th century Roma people who travelled around Europe with various letters of recommendation, stating, for example, that they were on a pilgrimage of penitence. Their exoticism was, however, soon replaced by suspicion. In 1637, a royal decree was introduced that declared all Gypsies outlaws; they could be deported immediately or beheaded for any crime without a court decision. The law was unique in Swedish history both in its severity and execution, although it was never carried out in practice because of its apparent misfit with the Swedish juridical system. ${ }^{18}$ In addition, the church took a negative stance toward the Roma who were denied all services provided by the church. However, examples of individual priests who opposed the orders from above and offered ceremonies to the Roma are also found here. The suspicious attitude nevertheless augmented an understanding of the Roma as a group of people with an outsider status and a controversial relationship with state authorities.

As a result, many Gypsies concentrated in the Finnish parts of the Swedish-Finnish kingdom where the grip of the state authorities was weaker. Finland's new status in 1809 as an autonomous part of Russia offered opportunities for the Finnish Roma to maintain their culture. This is in contrast to the Roma living in Sweden who gradually merged with other traveler groups, often called "tattare" in historical literature. 19 While the Roma life in Finland was by no means without hardship, they often nevertheless managed to gain a local reputation as skillful agricultural laborers, especially in relation to horses. Until the 1950s, Finnish Roma thus managed to adapt their mobile way of life and culture to the structural demands of agrarian society.

Meanwhile, in Sweden the situation was different. A committee report on the Roma situation in Sweden (The Committee on Legislation Concerning Poor Relief, the so-called Lösdriverutredningen) from 1923 concluded that "[a]s the Gypsies' conformation to our society appears to be an insoluble problem, the only expediency is, in one way or another, to get the gypsies out of the country." The majority of them, however, were considered Swedish subjects and could thus not be deported. The only possible solution and policy recommendation, according to the report, was to place "such robust restrictions on their freedom of movement that they find it is to their own advantage to leave the country". ${ }^{20}$

As part of their work, the committee consulted police districts with the aim of finding out where in the country Gypsies were causing problems and how the police dealt with them. The responses showed highly stigmatized notions of the Roma. They were described as "dirty," "ugly," "untrustworthy," "useless," and "a danger to society" by the police authorities. ${ }^{21}$ Some police districts declared that they had succeeded in getting rid of the troublesome groups: "Through the consistent application of sustained attentiveness, constant arrests for every offence and ensuing interrogation, detention or warnings for vagrancy, all tattare, with the exception of one family, have seen fit to leave the town." 22 In Sweden, other forms of government-approved repression against the Roma included work camps, children's homes, and legitimized forced sterilization programs until the late 1970s, whereas the Finnish policy was more toward assimilation through welfare state services.

\footnotetext{
17 Records of the Stockholm city council, September 29, 1512, printed in Stockholms stads tänkeböcker 1474-1592 [Stockholm town books]. Stockholms stads tänkeböcker från äldre tid II:1-5, Ny föjld 1-8, edited by E. Hildebrand, G. Carlsson, and J. A. Almquist. (Stockholm: Kungliga Boktryckeriet P.A Nordsted \& Söner, 1917-1948), $272-73$.

18 Pulma, Suljetut ovet, 24-25.

19 Pulma, Suljetut ovet, 48. The Swedish term, "tattare," should not be confused with the group of Muslims living in Finland and known as Tatars who emigrated from Russia (see Henrik Mattjus' chapter in this book). In addition to the first Roma in Sweden, often called Romani Travelers, new groups of Roma entered Sweden both at the end of the $19^{\text {th }}$ century (often called Swedish Roma) and in the 1950s and 1960s (called Finnish Roma or Non-Nordic Roma according to their country of origin).

20 SOU 1923:2 Förslag till lag om lösdrivares behandling m. fl. författningar [Draft law on travelers' treatment etc. provisions] (Stockholm: Socialdepartmentet, 1923), 89.

21 Ds 2014:8. The Dark and Unknown History: White Paper on the Abuse and Violations of Roma during the 20th Century

(Stockholm: Ministry of Culture, 2015), 39.

22 Questionnaire response from Ystad's police superintendent, HV, Committee on Legislation concerning Poor Relief, National Archives, quoted in DS 2014:8, The Dark and Unknown History, 40.
} 
During the last 50 years, the Roma have made advances in terms of education, working life, and other social participation. The differences between and within the Nordic policies is one of the reasons for the particularly strong position of Finnish Roma, even in Sweden. When the Nordic citizens became free to move and work in all of the Nordic countries, a considerable portion of Finnish Roma moved to Sweden, with the highest numbers occurring in the late 1960s. The reasons for this were typical of emigration at that time. Finland's structural change from an agriculture to an industrial society created the quest for a better life in terms of economic and social wellbeing, and Sweden seemed to offer the Roma both. ${ }^{23}$ This created a new dilemma for the Swedish authorities who were worried that the majority of the Finnish Roma would find Sweden a more appropriate place to live. ${ }^{24}$ A Finnish Roma couple named Grönfors were two immigrants looking for a new phase in their life. They moved to Sweden sometime in the 1960s and started a family. They lived in a small village close to the Finnish border and were engaged in horse trading.

\section{Fighting neighbors, hiding away racism: Family Grönfors}

On April 2, 2009, the Court of Appeal in Haparanda, Sweden found A. Grönfors, a son of the immigrated Grönfors, guilty of attempted murder. Four other members of the Grönfors (father, brother, and two sisters) were found guilty of abetting the attempted murder of their neighbor E. Rano. ${ }^{25}$ A. Grönfors had trespassed on Rano's property and attacked him with an axe. In his words, this was self-defense, as the family were afraid that Rano was going to shoot them. The court did not find this testimony convincing but grasped the case as a culmination of over 20 years of ongoing conflict between the family and their neighbors. Some neighbors had even been forced to move from their village because of the Grönfors' continuous harassment and verbal violence. In the court, a blurry surveillance video showing the course of the event was an important part of the evidence.

From the outset of the court hearings, the general opinion was strongly against the Roma family. Local and national newspapers reported on the conflict, often from very selective and one-sided points of view. For example, reporters listed previous police cases where members of the Grönfors family had been defendants, but left untold the cases reported to the police by the family. ${ }^{26}$ Both Swedish and Finnish television had broadcasted documentaries on the conflict throughout the 1990s and 2000s. ${ }^{27}$ In these documentaries, video footage and interviews with local inhabitants stood as testimony to the verbal and physical threats emanating from the Grönfors family. The prevailing questions raised by the media were: Why is such continuous immoral behavior tolerated in a welfare state? Why are various authorities - the municipality, the state, social services, and the police - powerless to handle the situation and, instead, just keep bouncing responsibility between them?

\footnotetext{
23 Inka Linnea Jeskanen, "Ja niin meki lähdettii sitte Ruotsii." Suomen romanien muutto Ruotsiin 1960-1980-luvuilla muistelukerronnassa ["And so we left for Sweden, too." Narratives of Finnish Roma who emigrated to Sweden in 1960s1980s] (Master's Thesis, University of Helsinki, 2012), passim. See also, Marianne Junila, "From Dynamic to Declining: Mass Emigration from Northern Finland to Sweden, 1960-75," in Imagining Frontiers, Contesting Identities, edited by Steven G. Ellis and Lud'a Klusáková (Pisa: Esizioni Plus - Pisa University Press, 2007), 309.

24 Ds 2014:8. The Dark and Unknown History, 163-65.

25 The district court had earlier convicted a third brother for abetment, but the Court of Appeal did not find evidence of his involvement in the case. A. Grönfors was sentenced to eight years' imprisonment, while the father and his brother received six-year sentences. The two sisters as well as a friend of the family were sentenced to six months for covering up the crime. The Supreme Court did not address the case despite the family's appeal. Haparanda tingsrätt, mål nr B 329-08; Hovrätten för Övre Norrland, mål nr B 972-08 / B 105-09.

${ }^{26}$ See Tommy Lundqvist, "Tjugo års fejd som ingen har lyckats få stopp på [Twenty years of conflict no-one has managed to put to an end]," NSD November 14, 2008, accessed January 5, 2017, http://www.nsd.se/nyheter/tjugoars-fejd-som-ingen-har-lyckats-fa-stopp-pa-4167970.aspx. Tommy Lundqvist, "Fadern och tre söner åtalas [Father and three sons prosecuted]," NSD 14.11.2008, accessed January 5, 2017, http://www.nsd.se/nyheter/fadern-och-tre-soneratalas-4167812.aspx. Sofia Strandberg, "Nu avgör rätten 20-årig grannkonflikt [The twenty-year neighbor conflict is now judged by the Court]," Svenska Dagbladet December 11, 2008, accessed March 4, 2017, http://www.svd.se/nuavgor-ratten-20-arig-grannkonflikt/om/sverige.

27 The TV shows covering the neighbor conflict include: Karpolla on asiaa [Karpo has something to say], "Kirkkoherran kiirastuli [Vicar's purgatory]", hosted by Hannu Karpo. MTV3, November 25, 1999; Insider TV3, "Grannfejden i Vojakkala [Neighbor feud in Vojakkala]", hosted by Robert Aschberg, Swedish TV3, April 2007; Uppdrag Granskning [Mission: Investigation], "Reportage: De övergivna [Report: The abandoned]", written by Janne Josefsson and Karin Mattisson, The Swedish Television Company, September 3, 2008; Silminnäkijä [Eye-witness], "Naapurihelvetti [Neighbor hell]", Finnish Broadcasting Company TV2, October 23, 2008; Karpon parhaat [The Best of Karpo], hosted by Hannu Karpo. MTV3, August 8, 2009.
} 
No one knew how it all had begun, nor how to put an end to it. What was known - or claimed to be known about the history of the family was that their move to Sweden in the 1960s had not been the typical story of searching for a better life. Instead, it was one of escaping involuntary treatment for mental illness they would have faced in Finland. They first lived in a caravan, as did many Roma families at that time, and later in a communal apartment in the Pitea community. According to rumors, the family caused so much trouble that the Piteå community simply wanted to get rid of them. In the 1980s, Pitea bought the family a house in Vojakkala village and offered them and Haparanda city "a considerable amount of money." In Vojakkala, the newcomers were noticed immediately; they were Gypsies, some with apparent mental illnesses. ${ }^{28}$ How these "qualities" affected the existing social relations within the village must have varied individually, but as seen through the general history of Roma settlements within hostile majority populations, ${ }^{29}$ those in power hardly wished for the family to acculturate and integrate into the village.

Discussion threads linked to the programs and newspaper articles predominantly cited the family as the cause for the conflict. None of the documentaries or newspaper articles mentioned the ethnic background of the family. Yet, everyone knew that the Grönfors were a Finnish-speaking Roma family. Commentators viewed the absence of recognizing the Grönfors' Roma background in the media as evidence of the state authorities' fear of being stigmatized as racist. Commentators thus expressed their disbelief in the state authorities' capacity to end the conflict, suggesting that "a local hunting accident" or "accidentally setting off Molotov cocktails" might be reasonable solutions. The circulation of "evidence" of their disturbing actions, supported by histories of earlier unsuccessful attempts of Roma to assimilate in Sweden, led only to one conclusion: members of the Grönfors family were incapable of engaging in normal life within Swedish society.

As one commentator in an internet forum put it:

"This family should be executed, the whole bunch, so that no one with those genes will have offspring. I'm filled with so much anger when I see this, yikes! And the bastard woman who claims that Insider is a racist program and asserts that the whole family has been accused and uniustly treated, she doesn't fucking deserve anything other than a bullet in the head."30

The language of hate speech can be rude, as the above quotation shows. ${ }^{31}$ This particular internet forum is devoted to discussions of crime cases. One typical topic of discussion delves into the severity of convictions, with commentators often complaining that the courts' punishments are not harsh enough. At the same time as commentators point out the problematic relationship between the Roma and Swedish police - the oftenquoted belief that due to their cultural traditions ${ }^{32}$ and violent historical confrontations with the police, ${ }^{33}$ the Roma would not generally trust Swedish police - the suggested execution of all family members shows, of course, his/her own banal form of mistrust in the police. Yet, the commentator's solution (i.e., getting rid of the Roma) resonates with the official policy carried out by the Swedish state until the late 1970s. Anonymously, many respondents express their disappointment in "not getting rid of the Gypsies decades ago" when Sweden already had the sterilization program running effectively. In addition, while the family history of the Grönfors is linked with the general history of the Roma in Sweden, the present "utopian idea of a multicultural Sweden" is illustrated through the killing of those who stand for minorities and see racism everywhere.

\footnotetext{
${ }^{28}$ Alistar pseud., May 25, 2012 , post to the thread "Grannfejden i Vojakkala," Flashback.org, accessed November 17 , 2016, https://www.flashback.org/p37530589\#p37530589.

29 The Roma were facing a double problem after the Second World War as their travelling way of life become unstable and their settling down was often objected to locally. This even caused violent confrontations, as in the case of the Pankakoski cleaning in the Finnish municipality of Lieksa where local inhabitants evicted Roma families from their homes. See, Miika Tervonen, "Romanit ja suuri muutos [The Roma and the great transition]," in Suomen romanien historia [The history of the Finnish Roma], edited by Panu Pulma (Helsinki: Suomalaisen Kirjallisuuden Seura, 201 2), $186-87$.

30 RickardTheBrave pseud., November 27, 2008, post to the thread "Insider - Vojakkala-familien [Insider: Vojakkala family]," Flashback.org, accessed February 3, 2017, https://www.flashback.org/ł793123p2.

${ }^{31}$ See also Tamas Gellert, Det svenska hatet: en berättelse om vår tid [The Swedish hate: a story of our time] (Stockholm: Natur och kultur, 2016).

32 Martti Grönfors, "Social Control and Law in the Finnish Gypsy Community: Blood Feuding as a System of Justice," Journal of Legal Pluralism 24 (1986), 108.

33 Ds 2014:8. The Dark and Unknown History, 46.
} 
Those few discussants who do not take part in the collective hate speech express their views in a considerably careful manner, as is often the case with speakers who are aware of their possibly problematic turn in conversation in terms of alignment. ${ }^{34}$ They use softeners (such as "maybe") to downgrade their epistemic stance and to show that while they might be wrong, they are nevertheless unhappy about the truth claims made by previous discussants. Below, a commentator positions himself outside the local framework, emphasizing that his point of view is based on what has been available in the media. Thus, the possibility of biased information exists as he goes on to suggest that an alternative understanding of the conflict might be possible:

I live far, far away from Voiakkala, but l've seen the [TV programs about the] neighborhood feud and all that. It's of course easy to appreciate these things in one way because of what one has seen on TV, but yet there are usually always two sides to everything. I don't have any kind of idea how it is up there and what happens there, but I just thought l'd share with you an article I found [... Made me think about it a little. ...35

The referred article was written by Maciej Zaremba, a Polish-born Swedish journalist, and published in a major national newspaper. ${ }^{36}$ Zaremba travelled to Vojakkala and spent three months in the community talking to the locals, authorities, social workers, and police officers. Furthermore, he was the first reporter to listen to what the members of the Grönfors family had to say. ${ }^{37}$ Zaremba was surprised to find that the image portrayed by the media did not match the stories told to him by the locals. He asserted that the media's coverage of the family was a product of partial fabrication of impromptu facts. For example, all the TV documentaries used the same video material shot by neighbors, which only showed the peaks of aggression, and not the buildup of controversies between the family and the neighbors. In the documentaries, the same local inhabitants were always interviewed. Every time the family did something wrong, both local and national newspapers reported the family's actions with their names and close descriptions of what had happened. When the family had been the target of harassment (as several police reports over the years confirmed), the incidents were reported in only a few lines only and anonymously. Most importantly, the media coverage did not mention that the attacked neighbor was not a model citizen either. He had a criminal record and was known for his temper and violent behavior. Also, the fact that some members of the Grönfors family had been diagnosed with mental disabilities made the power relationship between the two parties uneven.

Zaremba posed the question whether the root cause of the problem was indeed at the local level, comprising anti-Gypsy attitudes. He also questioned the legality principles of the court decisions. The court could have been influenced by the mediated history of the conflict, categorizing the family as a terrorizing entity who had collectively planned the murder for several years. Zaremba believed that the jury did not take into consideration the context of the violent event in two significant ways. The first was that the victim had done very little to achieve living peacefully with the family. In fact, Rano had threatened to get rid of the Gypsies several times. These instances of everyday racism are typically not considered in crime cases against minorities. ${ }^{38}$ The second issue was that the Grönfors father and brothers were mentally disabled and, thus, unable to handle socially complicated situations. In sum, Zaremba linked the Grönfors case to the Swedish state's inability to deal with Roma issues.

\footnotetext{
34 Jakob Steensig, "Conversation Analysis and Affiliation and Alignment", in The Encyclopedia of Applied Linguistics, edited by Carol A. Chapelle (Oxford: Wiley-Blackwell, 2013), 944-48.

35 Anusponten pseud., April 28, 2012, post to the thread "Grannfejden i Vojakkala," Flashback.org, accessed April 15, 2017, https://www.flashback.org/p37071764.

${ }^{36}$ Maciej Zaremba, "En annan bild av Vojakkala [Another picture of Vojakkala]," Dagens Nyheter May 18, 2009, accessed December 17, 2016, http://www.dn.se/kultur-noje/kulturdebatt/en-annan-bild-av-vojakkala.

37 During the conflict, the two Grönfors sisters only shared their views of the conflict through one short telephone interview in the television series, Uppdrag granskning. They also contacted a Finnish television producer, Hannu Karpo, but declined to participate in the documentary once they found out that their neighbors were also taking part in the program. After the court decision, they appeared in a Swedish television talk show, see: Malou Efter tio [Malou after ten], "Vi skulle mördas och styckas [We were being killed and cut up]", hosted by Malou von Sivers, TV4 Sweden, September 28, 2009; Malou Efter tio, "Ni fråga inte romerna själva [You don't ask the Roma directly]", hosted by Malou von Sivers, TV4 Sweden, September 29, 2009.

38 Berit Wigerfelt and Anders S. Wigerfelt, "Anti-Gypsyism in Sweden: Roma's and Travellers' Experiences of Biasmotivated Crime," Internet Journal of Criminology (2015), 5, accessed January 10, 2017, https://media.wix.com/ugd/b93dd4_be0750143d6742188b5e09eaf4c8cal 8.pdf.
} 
The story was not over, however. Four years later, Rano was found murdered. The case was again reported nationwide. Rano was introduced as the victim of the Vojakkala axe crime, thus creating a temporal, if not even a causal connection between the two cases. ${ }^{39}$ In the crime-related internet forums, the speculations started immediately. Could someone from the Grönfors family, even though most of them were still in prison, be the murderer? Some of the commentators referred to Gypsy blood feuding as an alternative system of justice. 40 Someone from the Grönfors kin could have been given an order to assassinate him:

"I would think that his murderer comes from the Grönfors clan or from their closest circle of friends. The shooter lurks likely somewhere in Finland. We have previously witnessed how all types of scum shuttle so easily over the border up there."41

Even after the police authorities reported having arrested a suspect - who was in no way related to the Grönfors - the speculations did not end. Still today, short video clips from the feuding neighbors case circulate on the internet, and commentators frequently equate the attempted murder with the murder, proposing as fact that the Grönfors (or in the absence of the name, Gypsies collectively) were behind both atrocities. Due to the media attention and platforms where any video is potentially reframed to stand as evidence of something quite different, the video clips of the Grönfors family shouting vulgarities at their neighbors will never stop running. Their family name, typical of Finnish Roma, remains connected to any crime made by someone with the same family name. This is an example of creating an impromptu fact, a knowledge claim that is partly fact (someone from the family abused their neighbors), but partly a fabrication, a misguided composition of singular events (leading to abuse).

The distribution of impromptu facts makes it difficult for outsiders to make sense of the original course of events differently. After becoming aware of the Roma side of the neighbor-conflict story, new questions are prone to emerge irrespective of whether one believes that their story is more truthful than the other one. These questions open up themes that are common to many rural newcomers belonging to ethnic, cultural, or sexual minorities. Tolerating differences often requires that the newcomers do not challenge the prevailing social order. ${ }^{42}$ When this proves difficult or impossible, as was the case in Vojakkala, the means of making the newcomers feel unwelcome by the local population can be many, ranging from exclusion to open conflicts. Why would a violent person with a known criminal background and anti-Roma opinions want to move next "to the most abhorrent Roma family in Sweden"? Is it a legitimate claim to expect that the Roma are the ones who always have to move away because of their romanticized nomadic style of living? Are rural communities particularly challenging places for the Roma to live if their ways of living collide with the Swedish rural idyll?̣ 43

\section{An encounter with Eastern European Roma street beggars in Finland}

The case of Grönfors family offered a deeply personal illustration of the problems of local community relations and Roma life in contemporary Sweden. Could larger cities, which scholars characterize by mundane friendliness and greater tolerance for difference, ${ }^{44}$ provide an anonymous shelter for the Roma, with or detached from their (presumed) nomadic practices? While Nordic cities are historically a result of a mixture of various ethnic, cultural, and social groups of people, the Roma are not easily accommodated in cities either.

39 TV3 Dokumentär, "En annan del av värkligheten [TV3 Document: Another part of the truth]," written by Robert Aschberg, TV3, March 24, 2012.

40 On blood feuding, see Grönfors, "Social Control", 108.

${ }^{41}$ Spoke island pseud., April 25, 2012 , post to the thread "Grannfejden i Vojakkala," Flashback.org, accessed January 17, 2017, https://www.flashback.org/ $\$ 550824$ p 181 .

42 See Hanna-Mari lkonen and Samu Pehkonen, "Rural Men in Nordic Television Programs," in Sexuality, Rurality, and Geography, edited by Andrew Gorman-Murray, Barbara Pini, and Lia Bryant (Lanham: Lexington Books, 2013 ), 75.

43 This has been a central topic in the research on travelers in the United Kingdom context. See, Keith H. Halfacree,"Out of place in the country: Travellers and the 'rural idyll'," Antipode 28 (1996), 42-72. Sarah L. Holloway, "Outsiders in Rural Society? Constructions of Rurality and Nature-Society Relations in the Racialisation of English Gypsy-Travellers, 1869-1934," Environment and Planning D: Society and Space 21 (2003), 695-715.

44 Nigel Thrift, "But malice aforethought: cities and the natural history of hatred", Transactions of the Institute of British Geographers NS 30 (2005), 141. Hannes Weber, "Mehr Zuwanderer, mehr Fremdenangst? Ein Überblick über den Forschungsstand und ein Erklärungsversuch aktueller Entwicklungen in Deutschland," Berliner Journal für Soziologie 25 (2015), 398. 
This is true with the traditional Roma in Nordic countries, but especially with the newcomers, Eastern European Roma beggars entering Nordic countries and engaging in street begging.

The entry of Romania and Bulgaria into the EU in 2007 opened up new possibilities for the Roma, whose poor but relatively stable economic and social position within socialist systems had been crushed by the breakdown of communist regimes in the 1990s and by the outbreak of nationalist political agendas that led to open discrimination and racism toward the Roma. 45 In addition to these push factors, aspirations for improved living standards and prospects of finding work resulted in many Roma EU citizens moving to other EU countries. The Eastern European Roma are part of the internal tensions within the EU, which have been legally addressed somewhat differently by the member states but nevertheless produce similar marginalized living experiences for the Roma people. On one hand, the EU promotes equal rights for the Roma in the Eastern European member states; on the other hand, it pressurizes those countries to keep the Roma within their borders, thereby regulating their right to free movement as EU citizens. ${ }^{46}$ The Eastern European Roma are visible to the public exclusively through their engagement in begging.

The daily presence of beggars on the street creates a strong contrast between the image of the Nordic model welfare state and the problem of categorizing the Roma who are, in the traditional sense, neither tourists, nor migrant workers, nor asylum seekers. In Nordic countries, begging as a sustained means of livelihood has been banned since the 17th century through various vagrant legislations and has been considered non-existent since the introduction of the welfare state in the 1970s. Hence, the daily presence of beggars in the urban landscape has become a controversial issue. 47 Although the number of Eastern European Roma beggars arriving in Finland has been small - approximately 200-500 persons annually enter and leave Finland 48 compared to, for example, 40,000 Roma living in camps in Italy 49 and an estimated 12 million living in Europe 50 , some concerned citizens and politicians have found it difficult to cope with the "Roma problem." The Mayor of Helsinki, Jussi Pajunen, for example, identified street disorder explicitly with Roma beggars and argued for the need to stop the Roma's uncontrolled migration.

To curb this mobility and fight the resulting moral panic, both Finland and Sweden have taken steps toward legislation that would make begging illegal, as has been the case, for example, in Denmark.51 The problem with various draft laws has been their semi-hidden aim to tackle only non-Finnish Roma. In addition to ethnic discrimination, legal attempts have been criticized for being ineffective to battle "deceit, fraud, and organized crime" that are commonly believed to be linked to begging. 52 The assumption that only Roma beggars constitute a crime-related problem has been raised in the Finnish news media, 53 although this assumption has been shown to be incorrect elsewhere. ${ }^{54}$ Nevertheless, some citizens choose to explicate their anti-Gypsy attitudes and distrust toward state authorities through direct action on the street.

\footnotetext{
45 István Pogány, The Roma Cafe: Human Rights and the Plight of the Romani People (London: Pluto Press, 2004$), 7-8$.

46 Mikko Puumalainen, "Poissa silmistä, poissa mielestä. Romanikerjäläiset ja liikkumisvapaus [Out of sight, out of mind. Roma beggars and freedom of mobility]," in Kerjääminen eilen ja tänään [Begging in history and today], edited by Virpi Mäkinen, Virpi and Anne Birgitta Pessi (Tampere: Vastapaino, 2009), 122-30.

47 See Riitta Laitinen's chapter in this book. See also, Kaarlo Arffman, "Hyvinvointivaltion synty ja keriäämisen

katoaminen Pohjoismaista [The origins of the welfare state and the disappearance of begging in Nordic Countries]," in Keriääminen eilen ja tänään [Begging in history and today], edited by Virpi Mäkinen and Anne Birgitta Pessi (Tampere: Vastapaino, 2009), 193.

48 Miika Tervonen and Anca Loredana Enache, "Uusia tulijoita [New arrivals]," In Suomen Romanien historia [The history of the Finnish Roma], edited by Panu Pulma (Helsinki: Suomalaisen Kirjallisuuden Seura, 2012 ), 265.

49 Nando Sigona, "The Gypsy Problem'. The Roma in Italy: Stereotyping, Labelling and 'Nomad Camps'," Journal of Ethnic and Migration Studies 31 (2005), 741.

50 Anne Beate Reinertsen, "Writing Race Roma 3D: 'Put in Vase to Give Nice,' She Said-And Nobody's Here But Me," Qualitative Inquiry 20 (2014), 489.

51 Anna Britt Diuve et al., When poverty meets affluence. Migrants from Romania on the streets of the Scandinavian capitals (Oslo: The Rockwool Foundation, 2015), 10.

52 Stef Adriaenssens and Jef Hendrickx, "Street-level Informal Economic Activities: Estimating the Yield of Begging in Brussels," Urban Studies 48 (201 1), 24. Virpi Mäkinen, "Are there fundamental rights for Roma beggars in Europe?," Political Theology 14 (2013), 201-18.

53 Kari Alenius, "Beggars, scammers, discriminated against by the whole of Europe: Romania's Roma in Finnish tabloids, 2008-201 1," Revista Română de Studii Baltice și Nordice / The Romanian Journal for Baltic and Nordic Studies 4 (2012), 97-105.

${ }^{54}$ Diuve et al., When poverty meets affluence, $66,80$.
} 
One such person maintains a YouTube channel dedicated to videoed encounters with Eastern European Roma beggars. In these videos, an arrogant Finnish citizen, "a man of the law," approaches and engages in conversation with female Roma beggars. He does not engage in vigilantism or direct physical violence, but his provocative conversational practices relate to what Michael Shapiro calls "micropolitics of justice," "a process in which individuals and collectives are affected by legality/illegalities, such that they participate in a culture of feelings or sensibilities and subsequently engage in discursive encounters about what is just." 55 The man seeks to solve the problem, which he claims the Finnish authorities have turned a blind eye to. He contextualizes his encounters with Roma beggars as an individual effort to make "the Roma problem" visible and to remove the women from the street at least temporarily. According to him, people should not donate money to these women, who he claims are not real beggars living in poverty but "marionettes short-changed by the mafia." His aim is to portray Roma beggars as scammers, who are incompetent, "out of place," and "not like us," in much the same way as the online commentators in the Grönfors family case.

In face-to-face encounters taking place in urban public spaces, the formulation of derogatory turns-in-talk is open for contestation in a different manner than anonymous online commentating. The validity or accuracy of claims can be questioned or met with counterarguments. The man uses his knowledge of law and regulations as an argumentative tool to show his authority over the beggars. However, simply knowing the law does not make him eligible to enforce the law. He thus needs to build up the conversation in terms of his epistemic and deontic rights toward the beggars. These rights are not given entities but are always negotiated in interactions, as has been shown in conversation analysis literature. In short, conversations are built on participants speaking one at a time in alternating turns. The turns are then used to construct various tasks and to respond to previous comments. Epistemic rights refer to the participants' (assumed) right to believe or accept something as true, whereas deontic rights refer to their right to determine the other's future actions. 56 The man needs to enact particular interactional methods (for example, threatening) in order to read the law as someone who is not officially eligible to read the law (as opposed to, say, police officers or security guards). Likewise, the beggars resort to another set of methods to question his aggressive conduct or claims about their future actions. As the conversation takes place with a mixture of English, Finnish, and Romanian, it is not always clear how much the participants understand each other. Yet, what is noteworthy is that single mutually recognizable words such as "police" ("poliisi" in Finnish or "poliție" in Romanian) act as cooperative devices for interaction, as is the case in the extract below. The man approaches a group of three beggars who have already noticed him from a distance. Two women leave the place while one remains seated on the pavement. The man stops by a woman who indicates that she does not want to be filmed and that the man should go away. He continues harassing the woman: ${ }^{57}$

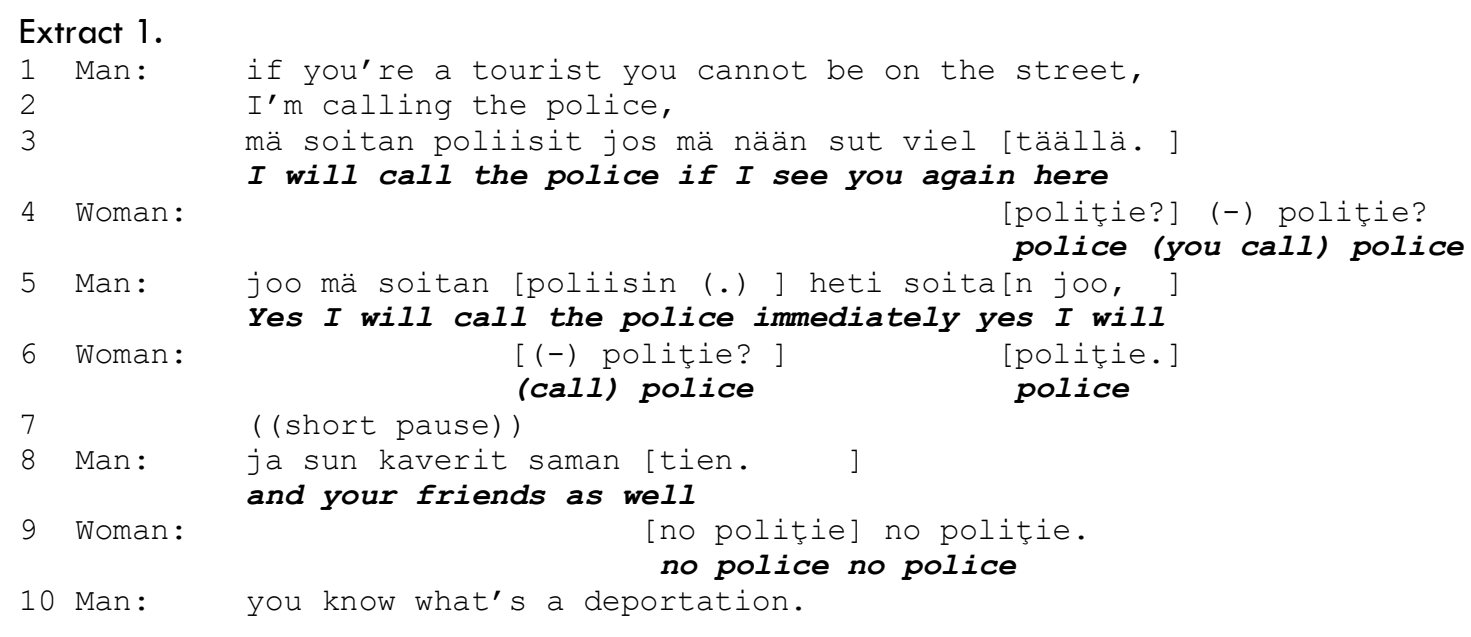

55 Michael J. Shapiro, "The Micropolitics of Justice: Language, Sense and Space," Law, Culture and the Humanities 8 (2012), 467.

56 On epistemic rights, see, Tanya Stivers, Lorenza Mondada and Jakob Steensig, "Knowledge, morality and affiliation in social interaction," in The morality of knowledge in conversation, edited by Tanya Stivers, Lorenza Mondada and Jakob Steensig (Cambridge: Cambridge University Press, 2011 ), 8-19. On deontic rights, see, Melisa Stevanovic and Anssi Peräkylä, "Deontic Authority in Interaction: The Right to Announce, Propose, and Decide," Research on Language and Social Interaction 45 (2012), 297-99.

57 Words in round brackets are indicative of what the speaker may have said. Square brackets indicate overlapping talk. 
The extract shows the turn-by-turn nature of negotiating participants' authority and rights in conversation. In the first line of the extract, the man formulates an epistemic claim about the identity of the woman as a tourist. It includes an authoritative statement about the rights and duties of such a group of people: tourists should have enough money to cover their expenses and should thus not have to resort to begging on the street. His epistemic right to treat the woman as a tourist is partly built on common knowledge - EU citizens' rights to enter another EU country - and is partly reinforced by the woman's inability to resist this categorization. He then extends his turn without pausing and transfers the epistemic authority to his deontic right to call the police who should remove the beggars (line 2). Instead of actually calling the police, he switches to Finnish (line 3 ) and reformulates his prior turn to a threat grammatically with a conditional clause ("if I see you again here"). The code switching between English and Finnish is part of his documentary method to capture the beggars as passive, void of their own agency. It is also a way of showing his power over the women who are (presumably) unable to understand Finnish and should thus feel excluded from the conversation they are reluctantly part of.

Although his threat might just be a rhetorical device without any reasonable material consequences in sight, the woman recognizes the single repeated word "police." This makes the presence of police a workable "resource" to both parties. On the video record, it is observable that the woman first looks in the direction of the other two women to avoid the man with the camcorder. Only after the man has uttered the word "police" twice does the woman glance at him, lift her right hand up, and repeat the word "police" with a rising intonation as a question of confirmation (line 4). Although some of the words in the woman's sentence are unclear, her turn with accompanying bodily gestures manifests a challenge to the threat formulated by the man. He reasserts his threat by saying that he will really call the police immediately (line 5 in Finnish). He also extends this threat to include all the women. The fact that the man continues to speak Finnish, a language the woman presumably cannot speak, might be read as an attempt to control the floor. The woman indicates that the police are not needed nor do they pose a real threat. The man continues to push further by asking a leading question about an even more severe possible outcome - deportation - that the calling of the police might result in for the women. Clearly, the man does not have the authority to decide whether these women could be deported from the country. However, seen from the point of view of his interactional project, he can continue harassing the women as long as his authoritative position remains unchallenged. As the man focuses the camcorder on her, she looks tired and irresolute.

A minute later, the man succeeds in his attempt to drive the women away. As the three women walk down the street, the man follows them and shouts derogatory comments. The women respond as best they can, with both gestures and words that are potentially recognizable over the language barrier.

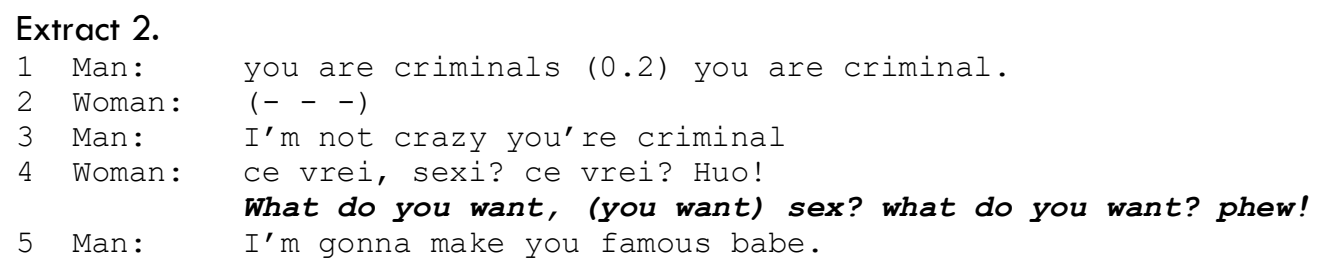

Calling the women criminals is a typical classification for the Roma people. Yet, the woman tries to redefine the situation with her turn (line 4), formulated as a suggestive question about the man's motives for engaging in face-to-face interactions with the women. She uses the argumentative method of building on gendered stereotypes as she suggests that the real criminal act under scrutiny is, in fact, the man who is trying to buy sex. The fact that this conversation takes place while moving in a public urban space redefines the situation as it opens up what was a private encounter into publicly heard harassment. 58

What these two short but detailed analyses of passing encounters reveal in relation to the broader discourses on the Roma people is the instrumental role individual Roma are given in the tensions between full-fledged citizens and those on the margins, between state authorities and legislative frameworks, as well as between established communities and increasing migration. The discourses build on the same stereotypical images of Roma as have been witnessed in historical and literary accounts, in various internet forums, and in public media reports on the Roma. The two distinct cases analyzed here - the Grönfors family and the harassed

${ }^{58}$ Carol Brooks Gardner, Passing by: Gender and Public Harassment (Berkeley: University of California Press, 1995$), 217$. 
female Roma beggars - are examples of taking away human dignity both from the individuals directly involved and the minority groups in general.

\section{Conclusions}

The aim of this chapter has been to oscillate between historical research on the Roma and the contemporary problematic relations that migration poses to different Roma groups. In a time of mass mediated information, there is plenty of newsworthy material to build chains of cause and effect, which then produce a relatively fixed landscape of power and community relations. 59 To discover how this power system operates, we need to become absorbed in an interpretative struggle with the circulation of various impromptu facts. As Finnish historian Panu Pulma argues, many beliefs about the Roma we have taken as facts have been proven myths by historical research. 60 The historiography of the Roma people has been mainly operated from the point of view of the majority of the population and society, thus lacking considerable efforts by the Roma population themselves. The Roma's mobile way of life provides an illustrative example. If the urge to travel is given as the primary explanation for their migration and, thus, identification of the Roma people, as was the case in early research on Roma culture, then we miss the interplay between economic strategies of the Roma and the economic possibilities provided by the majority of the population. The experiences of the two distinctive groups of Roma described in this chapter - the Finnish Kale and the Eastern European Roma -nevertheless face the same supranational discrimination, be it by legislative means or by more mundane racist commentaries. 61

This chapter has discussed the making of impromptu facts and moral panic mainly against the supposedly criminal activities of the Roma people. The often-mentioned saying that " $99 \%$ ruin the good reputation of the remaining 1\%" is certainly a fabrication and, at best, a pseudo-humorous one-liner. The moral panic is fabricated with the help of stereotypes, anecdotes, existing cases, and projected fears. For example, persons of Roma background (less than $0.2 \%$ of the total population of Finland) perpetrated $18 \%$ of solved robbery crimes in Finland in 2005, according to a report by The Finnish Ministry of Justice.62 This statistical fact is difficult to counter-argue except by attempting to look closer at the statistics and look for variables other than the self-evident ethnicity. For example, the Finnish Ministry of Interior sponsored website states that "crime is no more common among the Roma than among other Finns of similar socioeconomic status." 63 The end of the sentence - of similar socioeconomic status - is of enormous importance here. As the Grönfors case shows (as much as it reproduces the categorization of Roma as criminals), members of the Roma groups are capable of violent acts, but is this because of their ethnic identity or the socioeconomic possibilities of becoming decent citizens under the conditions of a weakening welfare state? The criminal behavior of certain individuals or families should not be generalized to cultural traits, 64 but at the same time, it should be noticed that the consequences of individual choices can be reflected in the community as a whole. As long as questioning the myths about the Roma or fighting against prejudices are not the central locus of discussion in public and academic domains, the all-inclusive society and the equality of individuals will remain a slow project.

\section{Bibliography}

Adriaenssens, Stef, and Jef Hendrickx. "Street-level Informal Economic Activities: Estimating the Yield of Begging in Brussels." Urban Studies 48 (2011): 23-40.

Ahmed, Sara. "A phenomenology of whiteness." Feminist Theory 8 (2007): 149-68.

\footnotetext{
59 Jonathan Smith, "The lie that blinds: destabilizing the text of landscape," in Place/Culture/Representation, eds. James S. Duncan and David Ley (London and New York: Routledge, 1993), 89.

60 Pulma, Suljetut ovet, 11-12.

61 Gasche, "State regulation of the Roma in Finland," 17.

62 Martti Lehti, Ryöstörikoskatsaus 2007 [Robbery Crime Report 2007] (Helsinki: National Research Institute of Legal Policy, 2008), 47.

63 "The culture of avoidance - does it still go on?," Romanit.fi, accessed January 20, 2017, http://www.romanit.fi/inenglish/traditions-and-customs/the-culture-of-avoidance-does-it-still-go-on/.

64 This has been the target of criticism in Bo Hazell's Resandefolket: Från tattare till traveller [Travelling folk: From 'tattare' to travelers] (Stockholm: Ordfront, 2011), 25-26 directed to Birgitta Svensson's dissertation Bortom all ära och redlighet - tattarnas spel med rättvisan [Beyond all honor and probity - Tatars' game with justice] (Stockholm: Nordiska museets förlag, 1993) which follows the life of two traveler families through seven generations and three centuries.
} 
Alenius, Kari. "Beggars, scammers, discriminated against by the whole of Europe: Romania's Roma in Finnish tabloids, 2008-201 1." Revista Română de Studii Baltice și Nordice / The Romanian Journal for Baltic and Nordic Studies 4 (2012): 87-109.

Arffman, Kaarlo. "Hyvinvointivaltion synty ja keriäämisen katoaminen Pohjoismaista [The origins of welfare state and the disappearance of begging in Nordic Countries]." In Keriääminen eilen ja tänään [Begging in history and today], edited by Virpi Mäkinen, and Anne Birgitta Pessi, 173-206. Tampere: Vastapaino, 2009.

Cohen, Stanley. Folk Devils and Moral Panics: The Creation of the Mods and Rockers. London: MacGibbon and Kee Ltd, 1972.

Diuve, Anna Britt, Jon Horgen Friberg, Guri Tyldum, and Huafeng Zhang. When poverty meets affluence. Migrants from Romania on the streets of the Scandinavian capitals. Oslo: The Rockwool Foundation, 2015.

Ds 201 4:8 The Dark and Unknown History. White Paper on the Abuse and Violations of Roma during the 20th Century. Stockholm: Ministry of Culture Sweden, 2014.

Gardner, Carol Brooks. Passing by: Gender and Public Harassment. Berkeley: University of California Press, 1995.

Garfinkel, Harold. Studies in Ethnomethodology. Englewood Cliffs: Prentice-Hall, 1967.

Garland, David. "On the Concept of Moral Panic." Crime, Media, Culture 4 (2008): 9-30.

Gasche, Malte. "State regulation of the Roma in Finland. The international dimension and the minority perspective." Siirtolaisuus/Migration 43 (2016): 17-21.

Gellert, Tamas. Det svenska hatet: en berättelse om vår tid [The Swedish hate: a story of our time]. Stockholm: Natur och kultur, 2016.

Grönfors, Martti. "Social Control and Law in the Finnish Gypsy Community: Blood Feuding as a System of Justice." Journal of Legal Pluralism 24 (1986): 101-25.

Halfacree, Keith H. "Out of place in the country: Travellers and the 'rural idyll". Antipode 28 (1996): 42-72.

Hazell, Bo. Resandefolket: Från tattare till traveller [Travelling folk: From 'tattare' to traveller]. Stockholm: Ordfron, 2011.

Höijer, Birgitta. "The Discourse of Global Compassion: The Audience and Media Reporting of Human Suffering." Media, Culture \& Society 26 (2004): 513-31.

Holloway, Sarah L. "Outsiders in Rural Society? Constructions of Rurality and Nature-Society Relations in the Racialisation of English Gypsy-Travellers, 1869-1934". Environment and Planning D: Society and Space 21 (2003): 695-715.

Horsti, Karina. "Hope and Despair: Representations of Europe and Africa in Finnish news coverage of "migration crisis'." Estudos em Comunicacao/ Communication Studies 3 (2008): 125-55.

Ikonen, Hanna-Mari, and Samu Pehkonen. "Rural Men in Nordic Television Programs." In Sexuality, Rurality, and Geography, edited by Andrew Gorman-Murray, Barbara Pini, and Lia Bryant, 67-79. Lanham: Lexington Books, 2013.

Jayyusi, Lena. "Values and Moral Judgment: Communicative Praxis as a Moral Order." In Ethnomethodology and the Human Sciences, edited by Graham Button, 227-51. Cambridge: Cambridge University Press, 1991.

Jeskanen, Inka Linnea. "Ja niin meki lähdettii sitte Ruotsii." Suomen romanien muutto Ruotsiin 1960-1980luvuilla muistelukerronnassa ["And so we left to Sweden too." Memory narratives of the Finnish Roma emigration to Sweden, 1960-1980s]. Master's Thesis, University of Helsinki, 2012.

Johansen, Nicolay B. "Controlling Roma in Norway: governing through the administration of social distance." In Punishing the Other: The Social Production of Immorality Revisited, edited by Anna Eriksson, 165-83. London and New York: Routledge, 2016.

Junila, Marianne. "From Dynamic to Declining: Mass Emigration from Northern Finland to Sweden, 1960-75". In Imagining Frontiers, Contesting Identities, edited by Steven G. Ellis, and Lud'a Klusáková, 303-17. Pisa: Esizioni Plus - Pisa University Press, 2007.

Lehti, Martti. Ryöstörikoskatsaus 2007 [Robbery Crime Report 2007]. Helsinki: National Research Institute of Legal Policy, 2008.

Lobo, Michele. "Everyday multiculturalism: catching the bus in Darwin, Australia." Social \& Cultural Geography 15 (2014): 714-29.

Mäkinen, Virpi. "Are there fundamental rights for Roma beggars in Europe?." Political Theology 14 (2013): 201-18.

Mäkinen, Virpi, and Pessi, Anne Birgitta, eds., Keriääminen eilen ja tänään [Begging in history and today]. Tampere: Vastapaino, 2009. 
Mayall, David. "Egyptians and Vagabonds. Representations of the Gypsy in Early Modern Official and Rogue Literature." Immigrants \& Minorities 4 (1997): 55-82.

Meinander, Henrik. "Nykyhistorian tutkimus: journalistiikkaa vai tiedettä [Contemporary history: journalism or science]." Tieteessä tapahtuu 1 (2001): 39-44.

Nacu, Alexandra. "The Politics of Roma Migration: Framing Identity Struggles among Romanian and Bulgarian Roma in the Paris region." Journal of Ethnic and Migration Studies 37 (201 1): 135-50.

Nickerson, Raymond S. "Confirmation Bias: A Ubiquitous Phenomenon in Many Guises." Review of General Psychology 2 (1998): 175-220.

Parker, Owen, and Óscar López Catalán. "Free Movement for Whom, Where, When? Roma EU Citizens in France and Spain." International Political Sociology 8 (2014): 379-95.

Pogány, István. The Roma Cafe: Human Rights and the Plight of the Romani People. London: Pluto Press, 2004.

Pulma, Panu. "Kun mustalaisleiri muutti kaupunkiin. Romanikysymys Helsingissä ja Tukholmassa 1950-luvulla [When Gypsies moved to town. Romani question in Helsinki and Stockholm in the 1950s]." In Ihmiset ovat kaupunki [People are the city], edited by Jari Niemelä, 175-94. Turku: Turun Historiallinen Yhdistys, 1999.

Pulma, Panu. Suljetut ovet. Pohjoismaiden romanipolitiikka 1500-luvulta EU-aikaan [Closed doors: Nordic Romani policy from the 16th century to the EU era]. Helsinki: Suomalaisen Kirjallisuuden Seura, 2006.

Pulma, Panu, ed., Suomen romanien historia [The history of the Finnish Roma]. Helsinki: Suomalaisen Kirjallisuuden Seura, 2012.

Puumalainen, Mikko. "Poissa silmistä, poissa mielestä. Romanikeriäläiset ja liikkumisvapaus [Out of sight, out of mind. Roma beggars and freedom of mobility]. In Keriääminen eilen ja tänään [Begging in history and today], edited by Virpi Mäkinen, Virpi and Anne Birgitta Pessi, 121-70. Tampere: Vastapaino, 2009.

Reinertsen, Anne Beate. "Writing Race Roma 3D: "Put in Vase to Give Nice," She Said-And Nobody's Here But Me." Qualitative Inquiry 20 (2014): 489-94.

Roman, Raluca B. "Trans-national migration and the issue of 'ethnic' solidarity: Finnish Roma elite and Eastern European Roma migrants in Finland." Ethnicities 14 (2014): 793-810.

Samra-Fredericks, Dalvir. "Ethnomethodology and the moral accountability of interaction: Navigating the conceptual terrain of 'face' and face-work." Journal of Pragmatics 42 (2010): 21 47-57.

Sigona, Nando. "Locating 'The Gypsy Problem'. The Roma in Italy: Stereotyping, Labelling and 'Nomad Camps'." Journal of Ethnic and Migration Studies 31 (2005): 741-56.

Simonsen, Anne Hege. "'Just like vacuum cleaning...': Reporting the Roma Beggar Tourists in Norway." In Media in motion: cultural complexity and migration in the Nordic region, edited by Elisabeth Eide, and Kaarina Nikunen, 89-105. Farnham: Ashgate, 2011.

Smith, Jonathan. "The lie that blinds: destabilizing the text of landscape." In Place/Culture/Representation, edited by James S. Duncan, and David Ley, 78-92. London and New York: Routledge, 1993.

SOU 1923:2 Förslag till lag om lösdrivares behandling m. fl. författningar [Draft law on travelers' treatment etc. provisions]. Stockholm: Socialdepartmentet, 1923.

Steensig, Jakob. "Conversation Analysis and Affiliation and Alignment." In The Encyclopedia of Applied Linguistics, edited by Carol A. Chapelle, 944-48. Oxford: Wiley-Blackwell, 2013.

Stevanovic, Melisa, and Anssi Peräkylä. "Deontic Authority in Interaction: The Right to Announce, Propose, and Decide." Research on Language and Social Interaction 45 (2012): 297-321.

Stivers Tanya, Lorenza Mondada, and Jakob Steensig. "Knowledge, morality and affiliation in social interaction. In The morality of knowledge in conversation, edited by Tanya Stivers, Lorenza Mondada, and Jakob Steensig, 3-24. Cambridge: Cambridge University Press, 2011.

Svensson, Birgitta. Bortom all ära och redlighet - tattarnas spel med rättvisan [Beyond all honor and probity Tatars' game with justice]. Stockholm: Nordiska museets förlag, 1993.

Tervonen, Miika. "Romanit ja suuri muutos [The Roma and the great transition]." In Suomen romanien historia [The history of the Finnish Roma], edited by Panu Pulma, 166-97. Helsinki: Suomalaisen Kirjallisuuden Seura, 2012.

Tervonen, Miika, and Anca Loredana Enache, "Uusia tulijoita [New arrivals]." In Suomen Romanien historia [The history of the Finnish Roma], edited by Panu Pulma, 265-68. Helsinki: Suomalaisen Kirjallisuuden Seura, 2012.

Thrift, Nigel. "But malice aforethought: cities and the natural history of hatred". Transactions of the Institute of British Geographers NS 30 (2005): 133-50.

Weber, Hannes. "Mehr Zuwanderer, mehr Fremdenangst? Ein Überblick über den Forschungsstand und ein Erklärungsversuch aktueller Entwicklungen in Deutschland." Berliner Journal für Soziologie 25 (2015): 397-428. 
Wigerfelt, Berit, and Anders S. Wigerfelt. "Anti-Gypsyism in Sweden: Roma's and Travellers' Experiences of Bias-motivated Crime". Internet Journal of Criminology (2015). Accessed January 10, 2017 https://media.wix.com/ugd/b93dd4_be0750143d6742188b5e09eaf4c8cal 8.pdf.

Zaremba, Maciej. "En annan bild av Vojakkala" [Another image of Vojakkala]. Dagens Nyheter, 18.5.2009, accessed December 17, 2016, http://www.dn.se/kultur-noje/kulturdebatt/en-annan-bild-avvojakkala. 